\title{
Accelerated Age-Related Cognitive Decline and Neurodegeneration, Caused by Deficient DNA Repair
}

\author{
Nils Z. Borgesius, ${ }^{1}$ Monique C. de Waard, ${ }^{2}$ Ingrid van der Pluijm, ${ }^{3}$ Azar Omrani, ${ }^{1}$ Gerben C. M. Zondag, ${ }^{3}$ \\ Gijsbertus T. J. van der Horst, ${ }^{2}$ David W. Melton, ${ }^{4}$ Jan H. J. Hoeijmakers, ${ }^{2}$ Dick Jaarsma, ${ }^{1}$ and Ype Elgersma ${ }^{1}$ \\ ${ }^{1}$ Department of Neuroscience, Erasmus MC, 3015 GE, Rotterdam, The Netherlands, ${ }^{2}$ Cancer Genomics Center, Department of Genetics, Center for \\ Biomedical Genetics, Erasmus MC, 3015 GE, Rotterdam, The Netherlands, ${ }^{3}$ DNage B.V., 2333 CR, Leiden, The Netherlands, and ${ }^{4}$ Institute of Genetics \\ and Molecular Medicine, University of Edinburgh, Medical Research Council Human Genetics Unit, Western General Hospital, Edinburgh EH4 2XU, \\ United Kingdom
}

Age-related cognitive decline and neurodegenerative diseases are a growing challenge for our societies with their aging populations. Accumulation of DNA damage has been proposed to contribute to these impairments, but direct proof that DNA damage results in impaired neuronal plasticity and memory is lacking. Here we take advantage of $\mathrm{Erccl}^{\Delta /-}$ mutant mice, which are impaired in DNA nucleotide excision repair, interstrand crosslink repair, and double-strand break repair. We show that these mice exhibit an agedependent decrease in neuronal plasticity and progressive neuronal pathology, suggestive of neurodegenerative processes. A similar phenotype is observed in mice where the mutation is restricted to excitatory forebrain neurons. Moreover, these neuron-specific mutants develop a learning impairment. Together, these results suggest a causal relationship between unrepaired, accumulating DNA damage, and age-dependent cognitive decline and neurodegeneration. Hence, accumulated DNA damage could therefore be an important factor in the onset and progression of age-related cognitive decline and neurodegenerative diseases.

\section{Introduction}

Accumulated DNA damage is thought to be an important factor underlying aging (Hoeijmakers, 2009). Several studies show that aging is accompanied by accumulation of neuronal DNA damage in rodents and humans (Sohal et al., 1994; Hamilton et al., 2001; Dorszewska and Adamczewska-Goncerzewicz, 2004; Gedik et al., 2005). Furthermore, the brain is particularly vulnerable to oxidative stress since it exhibits very high oxygen metabolism, has abundant lipid content and relatively low levels of antioxidants compared to other organs (Cai et al., 1996; Leutner et al., 2001; Serrano and Klann, 2004; Møller et al., 2010). Therefore, neurons may be especially prone to DNA lesions resulting from oxidative stress.

Evidence linking DNA damage to cognitive impairment follows from animals and patients receiving genotoxic chemother-

Received March 30, 2011; revised June 29, 2011; accepted July 20, 2011.

Author contributions: N.Z.B., I.v.d.P., G.C.M.Z., G.T.J.v.d.H., J.H.J.H., and Y.E. designed research; N.Z.B., M.C.d.W., and D.J. performed research; D.W.M. contributed unpublished reagents/analytic tools; N.Z.B., M.C.d.W., A.O., D.J., and Y.E. analyzed data; N.Z.B., D.J., and Y.E. wrote the paper.

This work was supported by a Top Institute Pharma grant to G.C.M.Z., J.H.J.H., and Y.E., and by an NWO-ZoNMW grant to Y.E. and G.T.J.v.d.H. Additional support is acknowledged from EU FP 7 (MarkAge 200880; Department of Genetics and DNage) and EU FP6 (Lifespan, EC-LSHG-CT-2007-036894; Department of Genetics) as well as grants from NIH (1P01 AG17242-02) and NIEHS (1U01 ES011044). J.H.J.H. and G.T.J.v.d.H. have a financial interest in DNage BV. The research was supported in part by DNage via the Top Institute Pharma, a public-private partnership consortium. G.C.M.Z. and I.v.d.P. are employed by DNage BV.

The authors declare no competing financial interests.

Correspondence should be addressed to either Ype Elgersma or Dick Jaarsma, Department of Neuroscience, Erasmus MC, P.0. Box 2040, NL-3000 CA Rotterdam, The Netherlands, E-mail: y.elgersma@erasmusmc.nl or d.jaarsma@erasmusmc.nl.

DOI:10.1523/JNEUROSCI.1589-11.2011

Copyright $\odot 2011$ the authors $\quad 0270-6474 / 11 / 3112543-11 \$ 15.00 / 0$ apeutic drugs (Ahles and Saykin, 2007; Konat et al., 2008). Additionally, mutations in DNA repair genes may cause neurological impairments, progressive neurodegeneration, and segmental accelerated aging as in a variety of progeroid conditions like xeroderma pigmentosum, Cockayne syndrome, and trichothiodystrophy, which are caused by defective nucleotide excision repair (NER) (Nance and Berry, 1992; Lehmann, 2003; Kraemer et al., 2007). However, in above examples, it cannot be ruled out that the cognitive dysfunction is secondary to the large impact of chemotherapy or progeroid syndrome on overall health.

Interestingly, increased oxidative DNA damage has been observed in subjects with mild cognitive impairments as well as late-Alzheimer's Disease (Keller et al., 2005; Wang et al., 2005; Lovell and Markesbery, 2007), suggesting a correlation between age-related accumulation of DNA damage and cognitive decline. However, a direct method to reliably quantify physiological levels of heterogeneous types of DNA damage in mammalian organs and tissues is extremely difficult (and controversial) and only possible for a very limited subset of lesions (Dizdaroglu et al., 2002). Moreover, there is a chicken and egg problem in the interpretation of studies trying to correlate neuronal degeneration with signs of DNA damage.

To circumvent these problems, we took advantage of a well established mouse mutant with a mutation in the excision repair cross-complementing group 1 ( $E r c c 1)$ gene. ERCC1 is involved in multiple DNA repair pathways: nucleotide excision repair (Houtsmuller et al., 1999), interstrand crosslink repair (Bergstralh and Sekelsky, 2008; Bhagwat et al., 2009), and double-strand break repair (Zhu et al., 2003; Ahmad et al., 2008). Consistently, ERCC1-deficient cells show increased sensitivity to agents or 
treatments that damage DNA, and hence it is expected that these animals accumulate DNA damage at a higher rate than control animals (Sijbers et al., 1996; Muñoz et al., 2005; Niedernhofer et al., 2006; Ahmad et al., 2008; Hoeijmakers, 2009). Recently it was shown that these animals have age-related neuronal changes in the spinal cord as well as in neuromuscular junctions of the skeletal muscle (de Waard et al., 2010). Here we show that global Ercc1 mutants as well as neuron-specific Ercc1 mutants exhibit an age-dependent decrease in neuronal plasticity, and progressive neuronal pathology, suggestive of neurodegenerative processes. These results suggest a causal relationship between unrepaired, accumulating DNA damage and age-dependent cognitive decline and neurodegeneration.

\section{Materials and Methods}

Generation and breeding of mutant mice. The generation and characterization of nucleotide excision repair-deficient $\mathrm{Erccl}^{\Delta /+}$ and $\mathrm{Erccl}^{-/+}$ mice has been previously described (Weeda et al., 1997). Ercc1 ${ }^{\Delta /-}$ mice were obtained by crossing $\mathrm{Erccl}^{+/-}$(in the C57BL6J background) with $\operatorname{Erccl}^{\Delta /+}$ mice (in the FVB background) to yield $\operatorname{Erccl}^{\Delta /-}$ with an F1 C57BL6J/FVB hybrid background. Wild-type littermates were used as controls. All animals used in the studies described in this paper were of the same F1 C57BL6J/FVB hybrid background. Typical unfavorable characteristics, like blindness in an FVB background or deafness in a C57BL6J background, do not occur in this hybrid background.

For the conditional mutant studies, we made use of a mouse line that has loxP sites inserted into its Erccl gene (floxed Erccl, Erccl ${ }^{f / f}$ ) (Doig et al., 2006). To achieve Erccl gene inactivation, we used a transgenic line with Cre recombinase under the control of the $\alpha$ CaMKII promoter (Tsien et al., 1996a,b). Expression from this promoter is specific for postmitotic excitatory neurons (Madisen et al., 2010). $\operatorname{Erccl}^{f /-}$ CaMKII$\mathrm{Cre}^{+}$mice were obtained by crossing $\operatorname{Erccl}^{f / f}$ (in the FVB background) with $\mathrm{Erccl}^{+/-} \mathrm{CaMKII-Cre}{ }^{+}$mice (in the C57BL6J background), to yield hybrid $\mathrm{Erccl}^{\mathrm{f} /-} \mathrm{CaMKII-Cre}{ }^{+}$mice. Erccl ${ }^{\mathrm{f} /-} \mathrm{CaMKII}-\mathrm{Cre}^{+}$mice are heterozygous for $E r c c 1$ in their entire body, except for the excitatory postmitotic neurons in the forebrain, which are homozygous for Ercc1 after Cre excision of the floxed allele. These mice will be referred to as $\mathrm{Erccl}^{\mathrm{fl}-}$ in the remainder of the study. As controls, we used $\mathrm{Erccl}^{f /+} \mathrm{CaMKII-}$ $\mathrm{Cre}^{+}$littermates (referred to as $\mathrm{Erccl}^{\mathrm{fl+}+}$ ), which are wild type in their entire body, except for the excitatory postmitotic neurons in the forebrain, which are heterozygous. For water maze learning and fear conditioning, we also included $\mathrm{Erccl}^{f /-} \mathrm{CaMKII-Cre} e^{-}$control mice, which are heterozygous for $\mathrm{Erccl}$ and not different from $\mathrm{Erccl}^{f /+} \mathrm{CaMKII-Cre}^{+}$ mice with respect to water maze learning and fear conditioning (data not shown).

Animals were screened for discomfort and weighed once a week. Animals were maintained in a controlled environment $\left(19-24^{\circ} \mathrm{C}, 12 \mathrm{~h}\right.$ light:12 h dark cycle), received standard rodent maintenance chow $[\mathrm{CRM}(\mathrm{P})$, Special Diets Services] and water ad libitum, and were housed in individual ventilated cages under SPF conditions. Erccl ${ }^{\Delta /-}$ mice received liquefied food when they were not able to reach the food due to movement disabilities. For all experiments, we used mice of both sexes. All animal experiments were approved by the Dutch Ethical Committee, and in accordance with Dutch animal care and use laws.

Antibodies. Primary antibodies [supplier; applications: immunohistochemistry (IHC); immunofluorescence (IF); and dilutions] reported in this study are as follows: rabbit anti-ATF3 (Santa Cruz Biotechnology; IHC, 1:1000); rabbit anti-GFAP (DAKO; IHC; 1:10,000; IF, 1:5000); rabbit anti-cleaved caspase 3 (Asp175, Cell Signaling Technology; IHC, 1:1000); mouse anti-MAP2 (clone AP20, Millipore; Sigma, IF, 1:200), rabbit anti-p53 (Leica; IHC, 1:1000), and mouse anti-NeuN (clone A60, Millipore; IF, 1:1000).

For avidin-biotin-peroxidase immunocytochemistry biotinylated secondary antibodies from Vector Laboratories, diluted 1:200 were used. FITC-, Cy3-, and Cy5-conjugated secondary antibodies raised in donkey (Jackson ImmunoResearch) diluted at 1:200 were used for confocal immunofluorescence.
Immunohistochemical and histopathological procedures. For immunocytochemistry and immunofluorescence, mice were anesthetized with pentobarbital and perfused transcardially with $4 \%$ paraformaldehyde. The brain was carefully dissected out and postfixed overnight in $4 \%$ paraformaldehyde. Routinely, brain tissue was embedded in gelatin blocks (Jaarsma et al., 2000) and sectioned at $40 \mu \mathrm{m}$ with a freezing microtome, and sections were processed, free-floating, using a standard avidin-biotin-immunoperoxidase complex method (ABC, Vector Laboratories) with diaminobenzidine $(0.05 \%)$ as the chromogen, or single-, double-, and triple-labeling immunofluorescence (Jaarsma et al., 2000; Vlug et al., 2005). In addition, a selected number of frozen sections were processed for a silver or thionine staining procedure that selectively labels dying neurons and their processes (Jaarsma et al., 2000).

Immunoperoxidase-stained sections were analyzed and photographed using a Leica DM-RB microscope and a Leica DC300 digital camera. Sections stained for immunofluorescence were analyzed with a Zeiss LSM 510 confocal laser scanning microscope. ATF3-, p53-, and cleaved caspase 3-positive cells were quantified in the neocortex of serial parasagittal sections [ $1-1.5 \mathrm{~mm}$ lateral from the midline; corresponding to plates 109-116 in the stereotaxic atlas of Paxinos and Franklin (2001)] using an Olympus microscope fitted with a Lucivid miniature monitor and Neurolucida software (MicroBrightField). Cells were plotted in an area of 3-6 $\mathrm{mm}^{2}$ (depending on the age and genotype of the mice) extending from the visual cortex to the frontal cortex and including all cortical laminae, and the number of labeled cells per square millimeter cortical area was determined.

Water maze. To test spatial memory, we used the water maze. Before the test, the mice were handled extensively $(2 \mathrm{~min} / \mathrm{d} ; 5 \mathrm{~d})$. Our pool is $1.2 \mathrm{~m}$ in diameter and has an $11 \mathrm{~cm}$ diameter platform submerged $1 \mathrm{~cm}$ below the surface. The water is painted milk-white with nontoxic paint and water temperature is kept constant at $26^{\circ} \mathrm{C}$. We used dimmed lighting, and mouse tracking is performed using SMART version 2.0 (Panlab). Mice were given 2 trials/d, with $30 \mathrm{~s}$ intertrial interval for 5 consecutive days. At a training session, the mouse was placed on the platform for $30 \mathrm{~s}$. Then it was placed in the water at a pseudorandom start position, and it was given a maximum of $60 \mathrm{~s}$ to find the platform. If the mouse did not find the platform in $60 \mathrm{~s}$, it was placed back on the platform. After $30 \mathrm{~s}$ on the platform, this training procedure was performed once more. The platform remained at the same position during all trials.

One hour after the training on day 5, a probe trial was given to test spatial learning. Mice were placed on the platform for $30 \mathrm{~s}$, after which the platform was removed and the mice were placed in the pool at the opposite side of the former platform location. The mice were then allowed to search for the platform for $60 \mathrm{~s}$.

Fear conditioning. Fear conditioning was performed in a conditioning chamber (Med Associates) equipped with a grid floor via which the foot shock could be administered. For context conditioning, each mouse was placed inside the conditioning chamber for $180 \mathrm{~s}$. A foot shock $(2 \mathrm{~s}, 0.4$ $\mathrm{mA}$ ) was delivered $148 \mathrm{~s}$ after placement in the chamber. Twenty-four hours later, context-dependent freezing was measured during 3 min.

Electrophysiology. After the animals had been killed, sagittal slices (400 $\mu \mathrm{m}$ ) were made and submerged in ice-cold artificial CSF (ACSF) using a vibratome, and hippocampi were dissected out. These sagittal hippocampal slices were maintained at room temperature for at least $1.5 \mathrm{~h}$ to recover before experiments were initiated. Then they were placed in a submerged recording chamber and perfused continuously at a rate of 2 $\mathrm{ml} / \mathrm{min}$ with ACSF equilibrated with $95 \% \mathrm{O}_{2}, 5 \% \mathrm{CO}_{2}$ at $31^{\circ} \mathrm{C}$. ACSF contained the following (in $\mathrm{mm}$ ): $120 \mathrm{NaCl}, 3.5 \mathrm{KCl}, 2.5 \mathrm{CaCl}_{2}, 1.3$ $\mathrm{MgSO}_{4}, 1.25 \mathrm{NaH}_{2} \mathrm{PO}_{4}, 26 \mathrm{NaHCO}_{3}$, and 10 D-glucose. Extracellular recording of field EPSP (fEPSPs) were made in CA1 stratum radiatum with platinum/iridium electrodes (Frederick Haer). A bipolar Pt/Ir was used to stimulate Schaffer-collateral/commissural afferents with a stimulus duration of $100 \mu \mathrm{s}$. Stimulus response curves were obtained at the beginning of each experiment, 20 min after placing the electrodes, with $10,2040,60,80$, and $100 \mu \mathrm{A}$ stimuli. For analyses, the data from the strongest stimulation were used. LTP was evoked using two different tetani: (1) $10 \mathrm{~Hz}$ ( 1 train of $10 \mathrm{~s}$ at $10 \mathrm{~Hz}$ ) and (2) $100 \mathrm{~Hz}$ (1 train of $1 \mathrm{~s} 100$ $\mathrm{Hz}$ ). The $10 \mathrm{~Hz}$ protocol was performed at two-thirds and the $100 \mathrm{~Hz}$ protocol at one-third of the maximum fEPSP. fEPSP measurements were 
done once per minute. Potentiation was measured as the normalized increase of the mean fEPSP slope for the duration of the baseline. Only stable recordings were included, and this judgment was made blind to genotype. Average LTP was defined as the mean last $10 \mathrm{~min}$ of each protocol. We used maximally two slices per mouse per protocol.

\section{Results \\ $\operatorname{Ercc1}^{\Delta /-}$ mice develop mild age-related neurodegenerative changes}

To examine whether a DNA repair defect is indeed sufficient to induce age-related neurodegeneration and cognitive decline, we made use of the $\operatorname{Erccl}^{\Delta /-}$ mouse mutant. This mutant carries a null mutation in one allele, whereas the protein derived from the second allele shows reduced activity, due to a 7 aa C-terminal truncation (Weeda et al., 1997). This hypomorphic mutation results in increased sensitivity to DNA damaging treatments such as gamma and UV radiation and Mitomycin C treatment, due to severely impaired nucleotide excision repair, interstrand crosslink repair, and double-strand break repair (Weeda et al., 1997; Niedernhofer et al., 2006; Ahmad et al., 2008). $\operatorname{Erccl}^{\Delta /-}$ mutants and their wild-type littermates were analyzed at 1 and 4 months of age. The age of 4 months was chosen since at this age animals display clear signs of premature aging, without significant mortality. The maximum lifespan of these mice in the genetically homogeneous F1 C57BL/6J-FVB/N hybrid genetic background used here is $\sim 6$ months (de Waard et al., 2010).

Macroscopically, the brains of $\operatorname{Erccl}^{\Delta /-}$ mice are smaller, but proportional to their reduced body size (de Waard et al., 2010). The gross histological organization analyzed in thionine stained sections appeared normal in all brain areas, including hippocampus (Fig. $1 A$ ), indicating that there is no evident developmental perturbation or massive neuronal degeneration. Immunostaining for glial fibrillary acidic protein (GFAP), which is known to be upregulated in response to neuronal injury and degeneration, showed increased GFAP staining, indicative of reactive astrocytosis, throughout the brain in 4-month-old $\operatorname{Erccl}^{\Delta /-}$ mice, while at 1 month GFAP staining was the same as in $\mathrm{Erccl}^{+/+}$mice (Fig. $1 A)$. These data indicate the occurrence of neurodegenerative changes in the $\operatorname{Erccl}^{\Delta /-}$ brain at 4 months of age but not at 1 month. Further analysis of thionine-stained sections revealed sporadic cells with pyknotic nuclei, indicative of cells undergoing apoptotic cell death, in hippocampus (Fig. $1 B$ ) as well as other brain areas of 4-month-old $\operatorname{Erccl}^{\Delta /-}$ mice. To further examine cell death, we immunostained for activated caspase 3, a final executioner caspase in multiple cell death pathways (Logue and Martin, 2008), and we used a silver staining method that selectively labels degenerating neurons and their axons. Caspase 3 staining revealed a low but distinctive number of labeled cells throughout the brain of 4-month-old $\mathrm{Erccl}^{\Delta /-}$ mice. In many occasions, labeled cells showed a clear neuronal morphology, while a subset of labeled cells showed a glial morphology (Fig. $1 B)$. Occasionally, caspase 3 -positive cells also occurred in the brain of 1-month-old $\operatorname{Erccl}^{\Delta /-}$ mice, albeit at a considerable lower frequency (Fig. 1C). In contrast, $\operatorname{Erccl}^{+/+}$mice did not show any caspase 3 -positive cells (Fig. 1C). Silver staining, similar to active caspase 3 immunostaining revealed a low level of neurons in the process of dying in multiple brain areas of 4-monthold $\operatorname{Erccl}^{\Delta /-}$ mice, including the hippocampal CA1 region and the dentate gyrus (Fig. 1D). The silver staining also produced argyrophilic staining of degenerating axons in white matter areas such an the corpus callosum, the fimbria-fornix, and the capsula interna bundles coursing through the striatum (Fig. 1D). The relatively more prominent argyrophilic staining of axons than of neuronal cell bodies may be explained by slower removal of degenerated axons resulting in cumulative argyrophilic staining in axonal trajectories (Jaarsma et al., 1992) even in conditions of a low level of ongoing neuronal death. Importantly, no, or very limited, axonal degeneration occurred in the white matter of 1-month-old $\operatorname{Erccl}^{\Delta /-}$ mice (Fig. $1 D$ ), consistent with the much lower levels of neuronal degeneration at this age as indicated by thionine-, active caspase 3-, and GFAP-stained sections. Together, our analyses of cell death and neuronal degeneration indicate that $\mathrm{Erccl}^{\Delta /-}$ mice show very sporadic cell death throughout the brain at 1 month, and considerably higher (albeit still modest) levels of ongoing cell death at 4 months of age. Finally, to further validate that the level of neuronal degeneration is limited and that a large proportion of neurons are preserved in hippocampus of 4-month-old $E r c c 1^{\Delta /-}$ mice, we stained for the somatodendritic neuronal marker MAP2. Indeed, as shown in Figure $1 E$, MAP2 staining in 4-month-old $E r c c 1^{\Delta /-}$ hippocampus appeared normal.

The asynchronous sporadically distributed neuronal degeneration in the $\operatorname{Erccl}^{\Delta /-}$ brain as outlined above is compatible with a model where neurons accumulate stochastic DNA lesions that eventually disrupt cell function. To obtain evidence that $\operatorname{Erccl}^{\Delta /-}$ neurons experience genotoxic stress, we have studied the expression of the transcription factor p53, which is known to be activated by multiple types of DNA damage and to mediate neuronal degeneration (Levine et al., 2006), and ATF3, which also is induced following genotoxic stress via p53-dependent and -independent pathways (Hai et al., 1999; Fan et al., 2002; Turchi et al., 2009). Already at 1 month of age, $\operatorname{Erccl}^{\Delta /-}$ mice showed cells with intensely p53-labeled nuclei throughout the brain, and this number was significantly increased at 4 months of age (Fig. $1 C, F)$. Instead, no p53-positive cells were observed in the nervous systems of $\mathrm{ErcCl}^{+/+}$mice (Fig. 1C). Double labeling with the neuronal marker NeuN showed that in cortex and hippocampus $>95 \%$ of the p53-positive cells were neurons (Fig. 1F). ATF3 labeling, like p53, was absent in most brain areas of $\mathrm{Erccl}^{+/+}$mice except for weakly labeled neuronal nuclei in the dentate gyrus, olfactory bulb, and pyriform cortex. However, significant amounts of cells with intensely labeled ATF3 nuclei occurred in the brain of $\mathrm{Erccl}^{\Delta /-}$ mice (Fig. 1C,G). Similar to p53, double labeling with NeuN indicated that the vast majority of ATF3positive cells were neurons (data not shown). The frequencies of ATF3-positive and p53-positive cells were $\sim 10$-fold the frequency of caspase 3-positive cells (Fig. 1C). Some p53- and ATF3-positive neurons displayed morphological abnormalities such as eccentric flattened nuclei, suggestive of compromised health (Fig. 1G). Together, these neuropathological data indicate that 4-month-old $\operatorname{Erccl}^{\Delta /-}$ mice show a low number of neurons in the process of dying while a greater number of neurons show signs of genotoxic stress and poor condition.

\section{$\operatorname{Ercc1}^{\Delta /-}$ mice show reduced hippocampal synaptic plasticity}

We investigated basal synaptic transmission properties of $\mathrm{Erccl}^{\Delta /-}$ mice, using fEPSP measurements of the Schaffercollateral pathway. The ratio between the fEPSP slope and the fiber volley, which is a measure of the efficacy of the synapses, did not differ significantly between genotypes at either 1 month or at 4 months of age, suggesting no changes in basal synaptic transmission [ratio $2.9 \pm 0.10(n=41$ slices from 9 animals $)$ and $2.7 \pm$ 0.11 ( $n=35$ slices from 8 animals) for 1 -month-old $E r c c 1^{+/+}$and $\operatorname{Erccl}^{\Delta /-}$, respectively; ratio $3.5 \pm 0.33(n=66$ slices from 20 animals) and $2.9 \pm 0.28$ (74 slices from 20 animals) for 4 -monthold $\mathrm{Erccl}^{+/+}$and $\mathrm{Erccl}^{\Delta /-}$, respectively; $F_{(1,74)}=2.5, p=0.11$; 
A
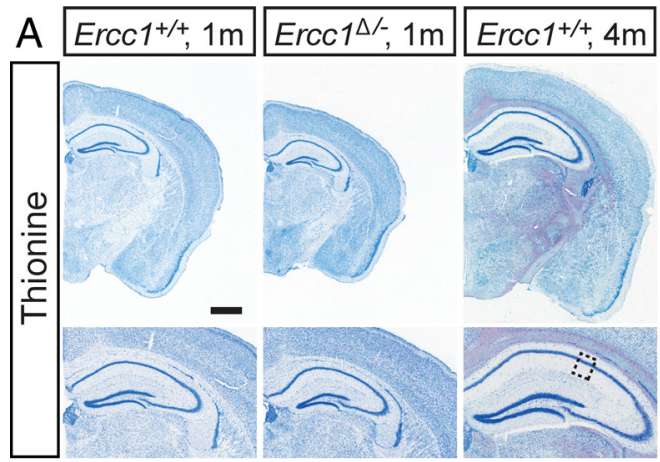

$\operatorname{Ercc1}^{\mathrm{L} /}, 4 \mathrm{~m}$
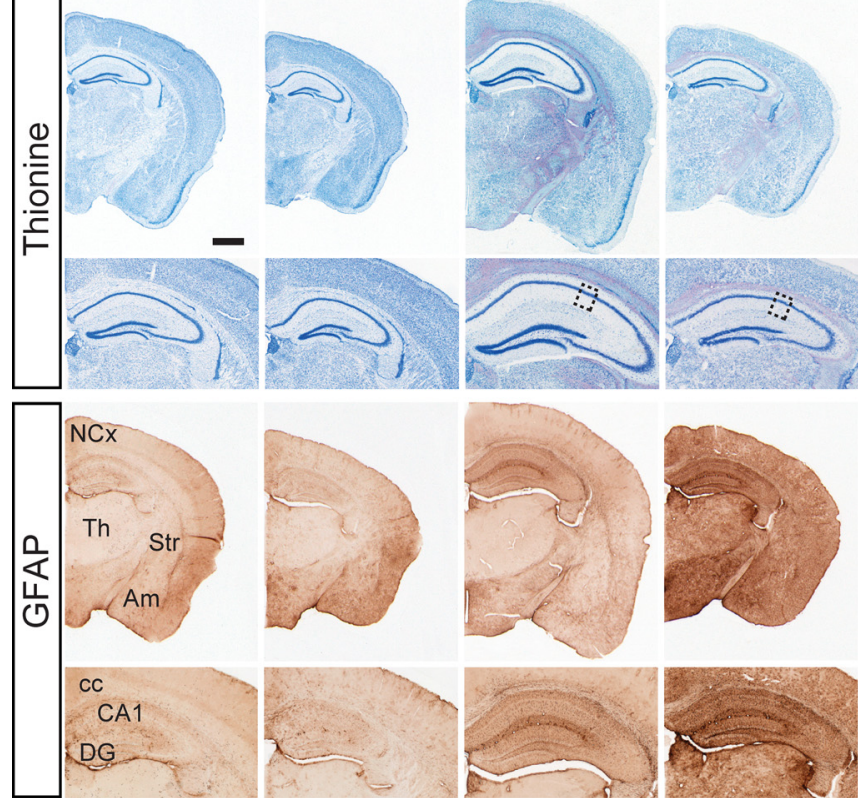

$B$
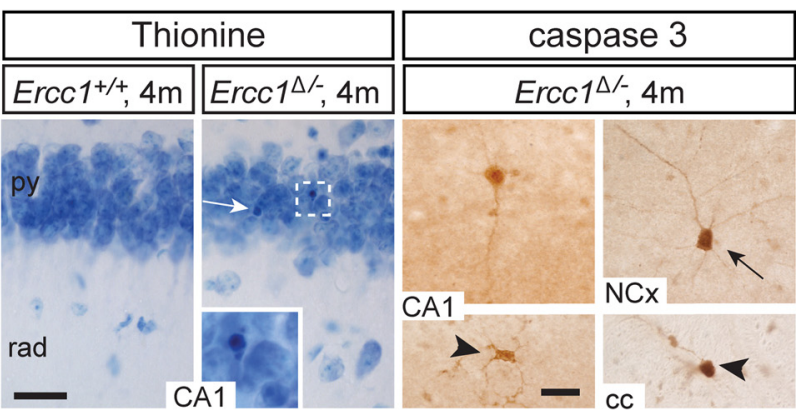

$\mathrm{C}$

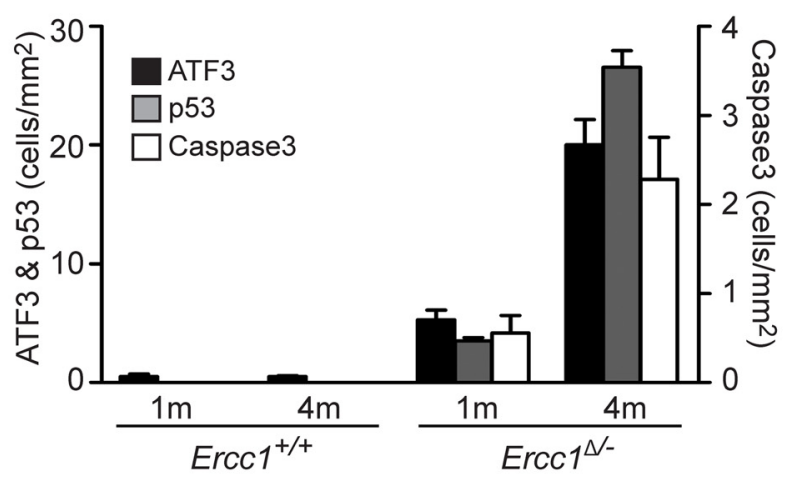

$\mathrm{D}$
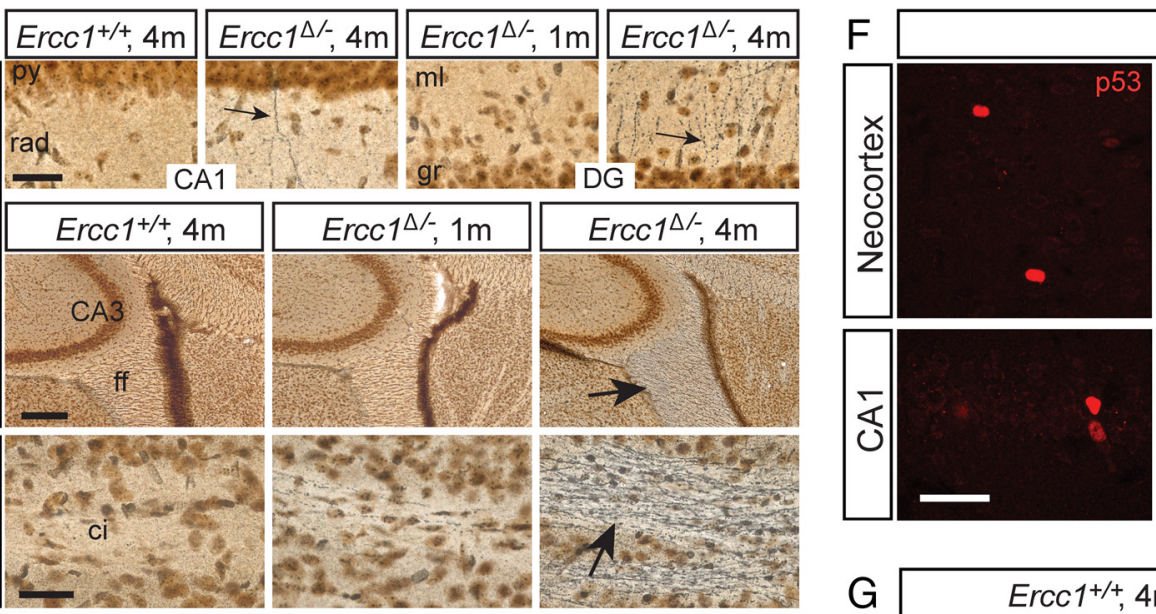

$\operatorname{Ercc}^{\Delta /-}, 4 \mathrm{~m}$
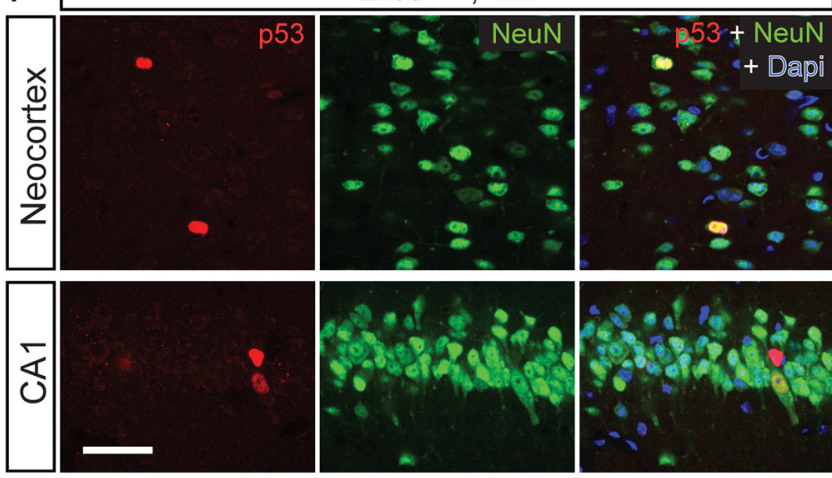

\section{$\mathrm{G}$}

$\operatorname{Ercc1}^{+/+}, 4 \mathrm{~m}$
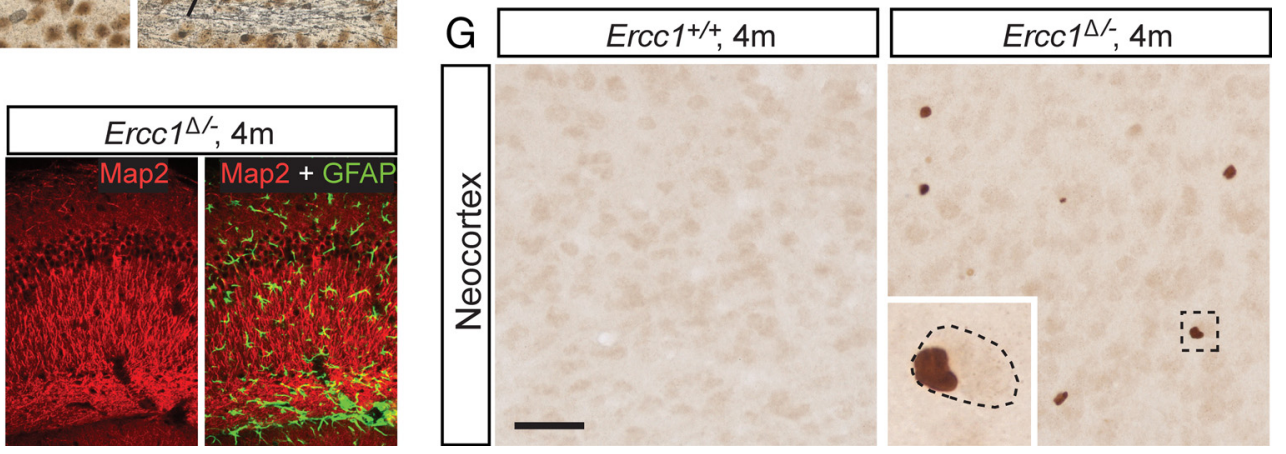

Figure 1. Young adult Ercc ${ }^{\Delta /-}$ mice display reactive astrocytosis, mild neuronal degeneration, and signs of genotoxic stress. A, Coronal brain slices stained with thionine (upper panels) or processed for GFAP immunoperoxidase histochemistry (lower panels) illustrating normal gross histoarchitecture of the dorsal hippocampus and surrounding brain structures in Ercc ${ }^{\Delta /-}$ mice, and increased GFAP staining throughout the brain of 4-month-old Ercc $7^{\Delta /-}$ mice (scale bar, $\left.500 \mu \mathrm{m}\right) . \boldsymbol{B}$, Light photomicrographs illustrating dying cells in hippocampus (CA1), cortex (NCX), and corpus callosum of 4-month-old Ercc ${ }^{\Delta /-}$ mice. Dying cells are identified by their pyknotic nucleus in thionine-stained sections (white arrow and inset in second image), or by active caspase 3 staining. In many occasions, caspase 3-positive cells can be easily differentiated in neurons (arrows) or glial cells (arrowheads; scale bar, $25 \mu \mathrm{m}$ ). C, Quantification of cortical cell density positive for ATF3, p53 or caspase 3 ( $y$-axis on left indicates values for ATF3 and p53; $y$-axis on the right indicates values for caspase 3). All data are reported as mean \pm SEM. Two-way ANOVA revealed a significant effect for genotype, age and their interaction for ATF3 (all $p<0.0001$ ), p53 (all $p<0.0001$ ), and caspase 3 (all $p<0.01$ ). D, Silver staining showing argyrophilic somatodendritic neuronal profiles indicative of dying neurons in 4-month-old Ercc ${ }^{\Delta /-}$ hippocampus (arrows in upper row; scale bar, $50 \mu \mathrm{m}$ ), and argyrophilic degenerating axons in fimbria-fornix (ff) (arrow in middle row; scale bar, $250 \mu \mathrm{m}$ ) and striatal capsula interna (ci) bundles (arrow in lower row; scale bar, $50 \mu \mathrm{m}$ ) of 4-month-old Ercc ${ }^{\Delta /-}$ brain. Note the absent and highly sporadic argyrophilic fiber degeneration in $\operatorname{Ercc}^{+/+}$mice and 1-month-old Ercc ${ }^{\Delta /-}$ brain, respectively. E, Confocal immunofluorescent images of CA1 area in the hippocampus showing unaltered level of MAP2 and increased GFAP immunoreactivity in 4-month-old Ercc $7^{\Delta-}$ mice (scale bar, $100 \mu \mathrm{m}$ ). $\boldsymbol{F}$, Confocal image showing p53-NeuN double-labeled cells in 4-month-old Ercc $7^{\Delta /-}$ cortex and hippocampus (scale bar, 50 $\mu \mathrm{m})$. G, ATF3-immunoperoxidase histochemistry illustrating multiple ATF3-positive cells in 4-month-old Ercc $7^{\Delta /-}$ cortex. Inset shows enlargement of neuron with flattened eccentric nucleus (scale bar, 100 $\mu \mathrm{m})$. Th, Thalamus; Str, striatum; Am, amygdala; cc, corpus callosum; DG, dentate gyrus; py, pyramidal layer; rad, stratum radiatum; ml, molecular layer; gr, granule layer. 

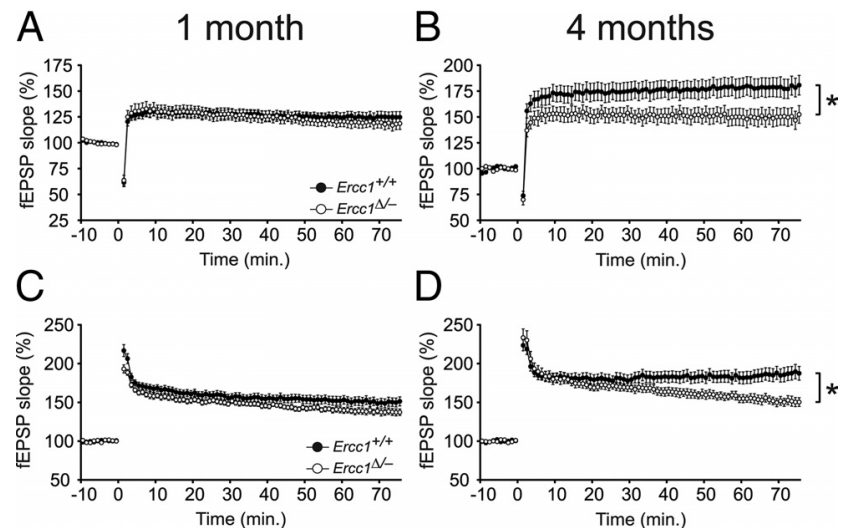

Figure 2. $\quad$ Ercc $7^{\Delta /-}$ mice show reduced synaptic plasticity at 4 months of age. $A, \operatorname{LTP}(10 \mathrm{~Hz})$ in 1-month-old mice shows no difference between $\operatorname{Ercc} 1^{\Delta-}$ and $\operatorname{Ercc} 1^{+/+}$mice $(n=14$ slices from 9 animals and $n=12$ slices from 8 animals for Ercc $1^{+/+}$and $\operatorname{Ercc} 1^{\Delta /-}$, respectively). $\boldsymbol{B}$, $\operatorname{LTP}(10 \mathrm{~Hz})$ in 4-month-old mice shows reduced LTP in Ercc $7^{\Delta /-}$ mice $[n=19$ slices from 10 animals and $n=18$ slices from 11 animals ( 4 males and 6 females) for ErcC ${ }^{+/+}$and Ercc $1^{\Delta /-}$, respectively]. C, LTP $(100 \mathrm{~Hz})$ in 1-month-old mice shows no difference between $\operatorname{Ercc}^{\Delta /-}$ and Ercc $1^{+/+}$mice $\left(n=17\right.$ slices from 9 animals and $n=12$ slices from 8 animals for Ercc $1^{+/+}$ and $\operatorname{Ercc}^{\Delta /-}$, respectively). D, LTP $(100 \mathrm{~Hz})$ in 4-month-old mice shows reduced LTP in Ercc $1^{\Delta /-}$ mice $(n=18$ slices from 10 animals and $n=17$ slices from 11 animals and for Ercc ${ }^{+/+}$and $\operatorname{Ercc}^{\Delta /-}$, respectively). All data are reported as mean \pm SEM. Filled circles represent $E r c c 1^{+/+}$. Open circles represent $\operatorname{Ercc} 1^{\Delta /-}$. ${ }^{*}$ Significantly different $(p<0.05)$ from age-matched Ercc $^{+/+}$mice.

$F_{(1,138)}=2.0, p=0.16$, one-way ANOVA for 1 month and 4 months old, respectively].

Synaptic plasticity can be assessed in vitro by measuring the ability of synaptic connections to become potentiated upon a train of high-frequency stimulation, a process known as longterm potentiation (LTP). LTP was induced at the Schaffercollateral synapse with a $10 \mathrm{~Hz}$ stimulus. Although LTP was observed in all groups, 4-month-old $\operatorname{Erccl}^{\Delta /-}$ mice showed significantly less LTP than their controls, whereas no significant difference was observed in 1-month-old mice, indicating normal initial functioning and accelerated, progressive decline of plasticity with age (Fig. $2 A, B ; F_{(1,24)}=0.6, p=0.40 ; F_{(1,35)}=5.3, p<$ 0.05 , one-way ANOVA for 1 and 4 months old, respectively). A reduction of LTP was also observed when using a strong $(100 \mathrm{~Hz})$ stimulus; 4-month-old $\operatorname{Erccl}^{\Delta /-}$ mice, but not 1-month-old $\operatorname{Erccl}^{\Delta /-}$ mice, displayed significantly reduced LTP compared to age-matched controls (Fig. $2 C, D ; F_{(1,27)}=2.7 p=0.10 ; F_{(1,33)}=$ $13.4, p<0.001$, one-way ANOVA for 1 month and 4 months old, respectively). These results show that $\operatorname{Erccl}^{\Delta /-}$ mice develop an age-related impairment of synaptic plasticity.

\section{A DNA repair defect exclusively in excitatory postnatal forebrain neurons causes gradual neuronal degeneration and reactive astrocytosis}

Although the aforementioned results showed that the global $\operatorname{Erccl}^{\Delta /-}$ mutation significantly affects neuronal health and plasticity, it cannot be ruled out that these outcomes are secondary to the reduced fitness of these animals due to liver, kidney, and other pathology (McWhir et al., 1993; Weeda et al., 1997; Selfridge et al., 2001; Lawrence et al., 2008; de Waard et al., 2010). To examine the direct effect of a DNA repair defect in neurons, and to rule out possibly confounding effects of systemic aging pathology, we made use of the Cre-loxP system to generate mutant mice with a neuron-specific ablation of Erccl.

$\mathrm{Erccl}^{\mathrm{f} / \mathrm{f}}$ mice containing a floxed $\mathrm{Erccl}$ gene were crossed with $\mathrm{Erccl}^{+/-}$CaMKII-Cre mice resulting in the desired Erccl ${ }^{f /-}$
$\mathrm{CaMKII}-\mathrm{Cre}^{+}$mice (hereafter referred to as $\mathrm{Erccl}^{f /-}$ mice), which are homozygous Ercc1 knock-outs in $\alpha$ CaMKIIexpressing cells (mostly excitatory postmitotic neurons of the hippocampus and cortex) and heterozygous for Erccl in the remainder of their body. As controls we used $\mathrm{Erccl}^{\mathrm{fl}-} \mathrm{CaMKII-}$ $\mathrm{Cre}^{-}$mice, which are heterozygous for the Erccl gene, and $\mathrm{Erccl}^{f /+} \mathrm{CaMKII-Cre}{ }^{+}$littermate controls, which are heterozygous for the $E r c c 1$ gene in the $\alpha$ CaMKII-expressing cells, and wild type in the rest of their body (hereafter referred to as $\mathrm{Erccl}^{f /+}$; see Materials and Methods). This breeding strategy was chosen instead of the preferred $\mathrm{Erccl}^{+/ f}$ with $\mathrm{Erccl}^{+/ f} \mathrm{CaMKII-Cre}$ breeding, because the latter breeding strategy frequently results in germ-line deletion of the floxed allele. Importantly, mice that are either heterozygous for $\operatorname{Erccl}\left(E r c c 1^{+/-}\right.$mice or $E r c c 1^{f /-}$ mice without Cre) do not show a phenotype with respect to lifespan, body weight, general appearance, brain pathology, and synaptic plasticity (Weeda et al., 1997 and data not shown).

Like $\operatorname{Erccl}^{\Delta /-}$ mice, the obtained $\operatorname{Erccl}^{f /-}$ mice showed an age-related increase in GFAP staining. However, increased GFAP staining was restricted to forebrain areas, in particular hippocampus and cortex (Fig. 3A), consistent with the Cre expressiondependent restricted ablation of Erccl in these mice. Changes in GFAP staining in hippocampus and cortex were detectable at the age of 4 and 6 months, but not yet at 2 months (Fig. $3 A$ ). Accordingly, immunohistochemistry for active caspase 3, p53, and ATF3 revealed no labeled cells in cortex and hippocampus of $\mathrm{Erccl}^{\mathrm{f} /-}$ mice at 2 months of age, while sporadic active caspase 3-positive cells and higher levels of ATF3- and p53-positive cells occurred at 4 and 6 months of age (Fig. $3 \mathrm{~B}, \mathrm{C}$ ). Positive cells only occurred in forebrain areas, again consistent with the restricted ablation of Ercc1. Regarding active caspase 3-labeled cells, we only observed cells with neuronal or undefined morphologies (Fig. 3B), but no labeled cells with clear glial morphologies such as observed in the brain of $\mathrm{Erccl}^{\Delta /-}$ mice (Fig. $1 \mathrm{~B}$ ). Also ATF3- and p53-positive cells were neurons, as $>95 \%$ was NeuN positive in double labeling experiments. The occurrence of neuronal degeneration in 4 and 6-month-old $\mathrm{Erccl}^{f /-}$ forebrain was further confirmed by silver degeneration staining producing sporadic argyrophilic neurons in the cortex and hippocampus, as well as argyrophilic fiber staining in the fimbria-fornix, capsula interna, and corpus callosum (data not shown).

In conclusion, these immunohistochemistry data show that the $\mathrm{Erccl}^{\mathrm{fl}-}$ mice have pathologies in hippocampus and cortex similar to those of the $\operatorname{Erccl}^{\Delta /-}$ mice, albeit that they develop at a somewhat slower time course, establishing a cell intrinsic cause of the neuronal phenotype and demonstrating that a DNA repair defect in forebrain neurons is sufficient to cause increased expression of markers that are indicative for genotoxic stress and neuronal degeneration.

\section{A DNA repair defect in excitatory neurons causes a reduction of LTP}

We studied the electrophysiological properties of the $\operatorname{Erccl}^{f /-}$ mouse hippocampus to determine whether neuronal DNA damage is sufficient to cause the aging-like phenotype at the level of synaptic plasticity. Similar to $\operatorname{Erccl}^{\Delta /-}$ mice, $\mathrm{Erccl}^{f /-}$ mice show no detectable impairment in synaptic transmission. The ratio between fEPSP slope and fiber volley does not differ at both 3 and 6 months of age [ratio $2.9 \pm 0.16(n=36$ slices from 5 animals) and $2.8 \pm 0.16$ ( $n=55$ slices from 12 animals) for 3-month-old $\operatorname{Erccl}^{f /+}$ and $\mathrm{Erccl}^{f /-}$, respectively; ratio $2.1 \pm 0.13(n=34$ slices from 5 animals) and $1.9 \pm 0.06$ (63 slices from 9 animals) for 6-month-old $E r c c 1^{f /+}$ and $E r c c 1^{f /-}$, respectively; $F_{(1,89)}=2.9, p=$ 
$0.09 ; F_{(1,95)}=2.2, p=0.14$ one-way ANOVA for 3 and 6 months old, respectively]. Next we investigated the ability to induce LTP at the Schaffer-collateral synapse using a $10 \mathrm{~Hz}$ stimulus. Although LTP was observed in all four groups, 6-monthold Erccl $^{f /-}$ mice showed significantly less LTP than their littermate Erccl ${ }^{f /+}$ controls, whereas no significant difference was observed for the 3-month-old mice (Fig. 4A, $B$; $F_{(1,33)}<0.001, p=1.0 ; F_{(1,23)}=5.8, p<$ 0.05 , one-way ANOVA for 3 and 6 months old, respectively). Similar results were obtained when a strong $100 \mathrm{~Hz}$ stimulus was applied: 6-month-old $\mathrm{Erccl}^{f /-}$ mice but not 3-month-old mice showed significantly reduced LTP as compared to their agematched controls (Fig. $4 C, D ; F_{(1,29)}=1.6$, $p=0.20 ; F_{(1,30)}=5.6, p<0.05$, one-way ANOVA for 3 and 6 months old, respectively). Hence, by restricting the defect in DNA repair to the excitatory neurons of the hippocampus, the mice are overall healthy, but hippocampal plasticity is still affected in an age-dependent fashion.

\section{A DNA repair defect exclusively in neurons causes impaired cognitive function}

Having shown that the $E r c c 1^{f /-}$ mice are physically in good condition, but with regard to the hippocampus still display an accelerated aging phenotype similar to the $\operatorname{Erccl}^{\Delta /-}$ mice, both in cellular pathology and in vitro synaptic plasticity, we tested the ability of the mutants to learn by using the Morris water maze test. In this test, which relies on a functional hippocampus, animals are trained over several days to locate a submerged platform in a circular pool filled with opaque water using distal visual cues. All four groups showed a significant reduction of their latency times to find the platform across training days (Fig. $5 A, B$; effect of training: $F_{(4,148)}$ $=28.5, p<0.001 ; F_{(4,124)}=21.4, p<$ 0.001 , repeated-measures ANOVA for 3 and 6 months old, respectively). There was no significant effect of genotype in both age groups (Fig. $5 A, B$; effect of genotype: $F_{(1,37)}=0.2, p=0.66 ; F_{(1,31)}=$ $3.7, p=0.06$, repeated-measures ANOVA for 3 and 6 months old, respectively), and swim speed was not different between genotypes $(18.1 \pm 1.0$ and $16.5 \pm 0.5 \mathrm{~cm} / \mathrm{s}$ for 3-month-old $\operatorname{Erccl}^{f /+}$ and $\mathrm{Erccl}^{f /-}$, respectively; $15.9 \pm 0.3$ and $16.3 \pm 0.7 \mathrm{~cm} / \mathrm{s}$ for 6-month-old $\mathrm{Erccl}^{f /+}$ and $\mathrm{Erccl}^{f /-}$, respectively; $F_{(1,37)}=3.3, p=0.08 ; F_{(1,34)}=$ $0.4, p=0.51$ one-way ANOVA for 3 and 6 months old, respectively). These data indicate that mice in all four groups were able to execute this task and motivated to

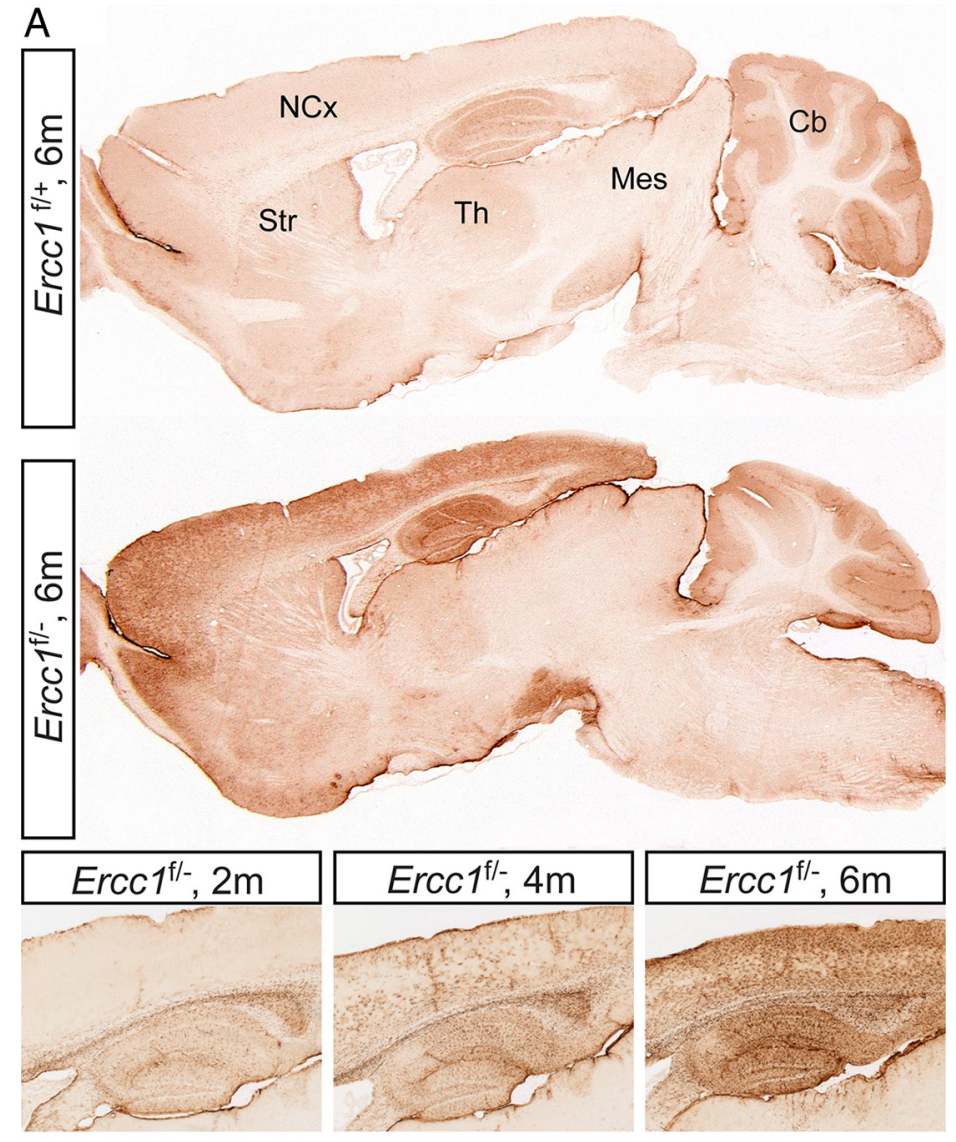

B
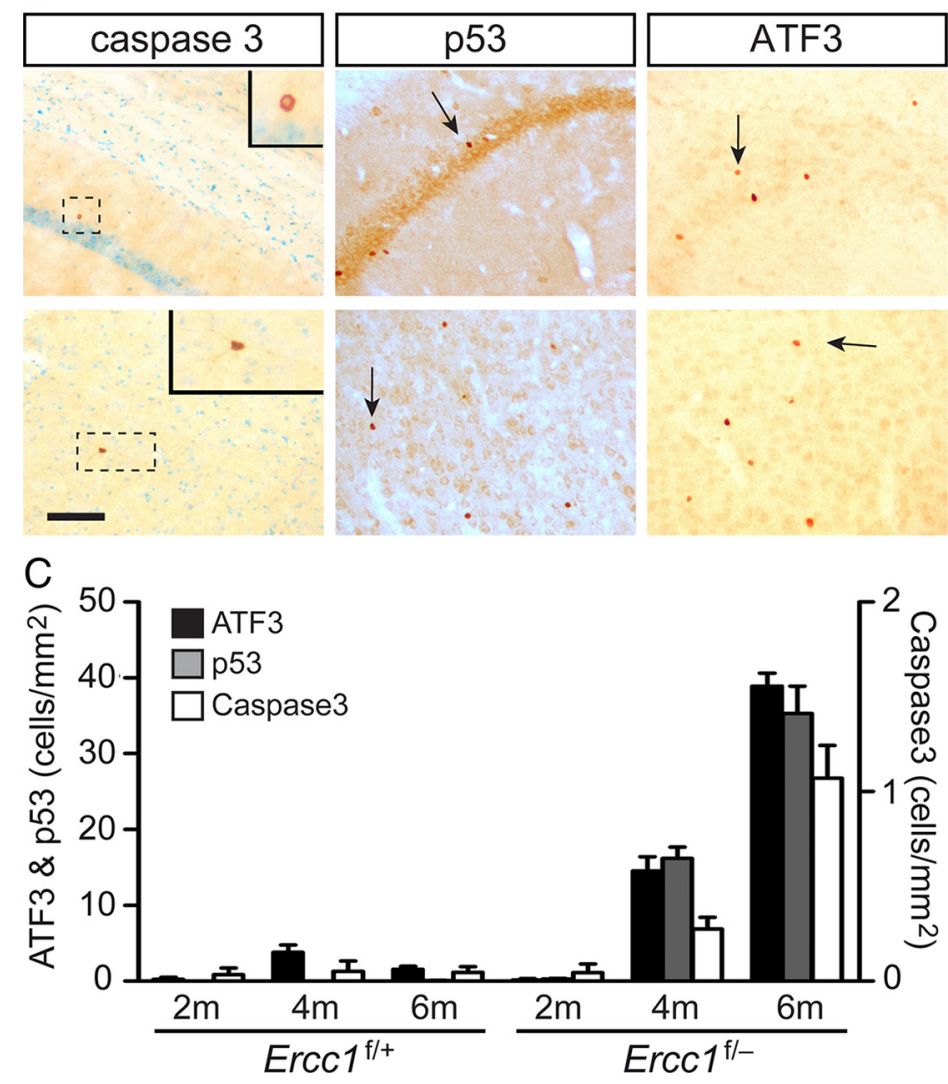

Figure 3. $\operatorname{Ercc}^{\mathrm{f} /-}$ mice show astrocytosis, genotoxic stress transcription factor expression, and mild age-related neuronal degeneration. A, GFAP-immunoperoxidase staining in sagittal brain section of Ercc $7^{f /-}$ and control $\left(\operatorname{Ercc}^{f /+}\right)$ mice. Note the 

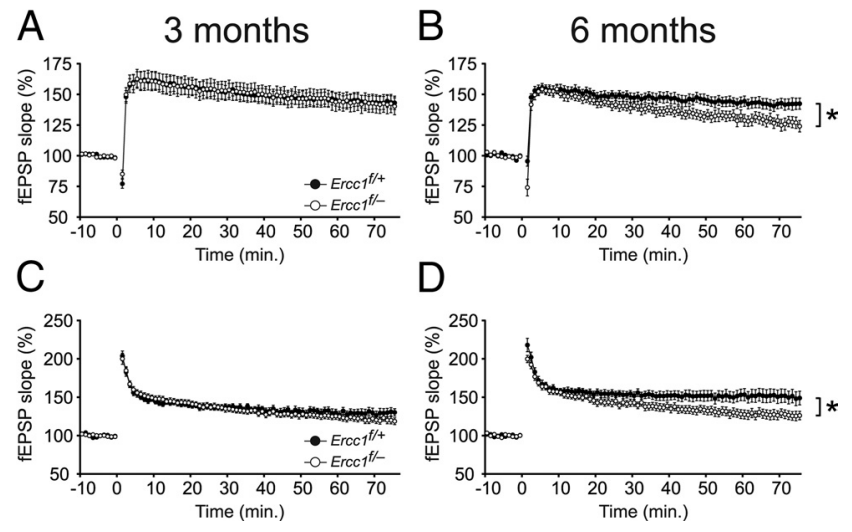

Figure 4. $\quad$ Ercc $\mathrm{T}^{\mathrm{f} /-}$ mice show reduced synaptic plasticity at 6 months of age. $A, \operatorname{LTP}(10 \mathrm{~Hz})$ in 3-month-old mice shows no difference between Ercc ${ }^{f /-}$ and Ercc $7^{f /+}$ mice $[n=16$ slices from 5 animals, $n=19$ slices from 8 animals for Ercc $7^{f /+}$ and Ercc ${ }^{f /-}$, respectively]. B, LTP (10 $\mathrm{Hz}$ ) in 6-month-old mice shows reduced LTP in Ercc $7^{f /-}$ mice $(n=14$ slices from 4 animals and $n=11$ slices from 5 animals for $\operatorname{Ercc}^{f /+}$ and Ercc ${ }^{f /-}$, respectively). C, LTP $(100 \mathrm{~Hz})$ in 3-month-old mice shows no difference between $\operatorname{Ercc}^{f /-}$ and $\operatorname{Ercc}^{7 /+}$ mice $(n=13$ slices from 4 animals, $n=18$ slices from 10 animals for Ercc $7^{f /+}$ and Ercc $7^{f /-}$, respectively). D, LTP (100 $\mathrm{Hz}$ ) in 6-month-old mice shows reduced LTP in $\operatorname{Ercc} 7^{f /-}$ mice $(n=15$ slices from 5 animals and $n=17$ slices from 7 animals for Ercc $7^{f /+}$ and Ercc $7^{f /-}$, respectively). All data are reported as mean \pm SEM. Filled circles represent Ercc ${ }^{f /+}$. Open circles represent Ercc $7^{f /-}$. ${ }^{* S i g n i f i c a n t l y ~}$ different $(p<0.05)$ from age-matched $\operatorname{Ercc}^{f /+}$ mice.

escape. To test whether the mutants had indeed learned the spatial location, a probe trial in which the platform was removed, was given after $5 \mathrm{~d}$ of training. This probe trial showed that all four groups of mice spent significantly more time in the target quadrant than in any of the other quadrants, indicating that the mutants had indeed learned the platform location at both 3 and 6 months of age (Fig. 5C,D). However, aged (but not young) mutants spend significant less time in the target quadrant than Erccl $^{f /+}$ littermate control mice $\left(F_{(1,34)}=4.8, p=0.03\right.$, one-way ANOVA) (Fig. $5 E, F)$. This deficit could be overcome by $2 \mathrm{~d}$ of additional training (data not shown), indicating that the mutants are able and motivated to learn the task, but it takes more training to reach a similar level of performance.

As an additional paradigm to test cognitive function, which is sensitive to hippocampal dysfunction, we made use of contextual fear conditioning. In this single-trial learning task, mice are conditioned to associate a certain context with a mildly aversive foot shock. This learning paradigm has been shown to require both a functional hippocampus as well as amygdala (Fanselow, 1990). Learning is assessed by measuring freezing behavior, i.e., the cessation of all movement except respiration, which is a natural

$\leftarrow$

strongly increased GFAP staining in forebrain regions, including neocortex (NCX), striatum (Str), and hippocampus, of 6-month-old Ercc $\mathrm{f}^{\mathrm{f} /-}$ mice while GFAP staining in other parts of the brain, including thalamus (Th), mesencephalon (Mes), and cerebellum (Cb) is the same as in control. The lower panels show that the increase GFAP staining in Ercc ${ }^{f /-}$ hippocampus and cortex starts after 2 months of age and is progressive. $\boldsymbol{B}$, Active caspase 3, p53, and ATF3immunoperoxidase histochemistry illustrating positive cells in 6-month-old Erec ${ }^{f /-}$ hippocampal CA1 area (upper row) and neocortex (lower row, scale bar $100 \mu \mathrm{m})$. C, Bar graph illustrating the density of ATF3- and p53- ( $y$-axis on left) and caspase 3 - ( $y$-axis on the right) positive cells in neocortex of Ercc ${ }^{f /-}$ and Ercc $7^{f /+}$ mice. Data represent means \pm SEM. Twoway ANOVA revealed a significant effect for genotype, age, and their interaction for ATF3 (all $p<0.001$ ), p53 (all $p<0.001$ ), and caspase 3 (genotype $p=0.01$, age $p=0.01$ and genotype $\times$ age $p=0.01$ ). Tukey HSD post hoc tests revealed significant effects between all age groups for ATF3 (all $p<0.001$ ) and for $p 53$ (all $p<0.001$ ). For caspase 3, Tukey HSD post hoc test revealed a significant difference between 2 and 6 months and 4 and 6 months $(p<$ 0.001 and $p=0.002$, respectively). expression of fear in mice. At 3 months of age, the freezing response of the $\operatorname{Erccl}^{f /-}$ mice was indistinguishable from that of their $\operatorname{Erccl}^{f /+}$ littermate controls (Fig. $5 G ; F_{(1,42)}=0.9, p=0.36$, one-way ANOVA). However, at 6 months the $\operatorname{Erccl}^{f /-}$ mice froze significantly less than their littermate $\operatorname{Erccl}^{f /+}$ controls (Fig. 5H; $F_{(1,40)}=5.7, p<0.05$, one-way ANOVA). Neither the 3-monthold groups nor the 6-month-old groups showed a difference in baseline freezing behavior (Fig. $5 G, H ; F_{(1,242)}=0.5, p=0.47$; $F_{(1,32)}=0.09, p=0.77$, one-way ANOVA for 3 and 6 months old, respectively), suggesting that reduced freezing is a consequence of the failure to form a contextual representation of the fear conditioning box, and not of reduced fear in general. The combination of reduced learning in the water maze, reduced levels of freezing after context conditioning, and the impaired hippocampal LTP strongly indicate impaired hippocampal function. However, we want to emphasize that the cognitive deficit is most likely not restricted to the hippocampus, but probably affects all the $\alpha$ CaMKII-expressing cells of the forebrain, as is also suggested by the pathological findings.

These results show that mice, in which the defect in DNA repair is limited to neurons, develop an age-related impairment of context-dependent fear learning.

\section{Discussion}

Although accumulation of DNA damage has been put forward as a potential cause for cognitive decline, there is no direct causal proof that a defect in DNA repair can induce cognitive deficits. This study shows that defective DNA repair, either in the entire body or in neurons alone, causes an accelerated aging-like phenotype of the brain with respect to both cellular pathology and synaptic plasticity deficits. In addition, we show that in otherwise healthy animals, homozygous deletion of Erccl restricted to $\alpha$ CaMKII-expressing neurons (mostly excitatory neurons of the forebrain) is sufficient to affect learning.

Our pathological data indicate that both the global and neuron-specific Ercc1 mutant mice, while showing respectively minimal and no degenerative changes at juvenile age, develop signs of genotoxic stress and mild neuronal degeneration as well as astrocytosis during young adult life. The increased expression of GFAP, indicative of reactive astrocytosis, in Ercc1 mutant mice is also seen in the brains normally aging rats, mice, and humans (O'Callaghan and Miller, 1991; Nichols et al., 1993; Takahashi et al., 2006). In addition, the increased p53 expression we found is observed in normal aging rat brain (Chung et al., 2000; Dorszewska and Adamczewska-Goncerzewicz, 2004). Together, these results show that (neuronal) DNA damage results in brain pathology that shares characteristics with normal aging. However, it is important to point out that although the Erccl mutants show global functional and structural deterioration; some aspects of neuroaging are not modeled, such as accumulation of lipofuscin and the aggregation of proteins.

The pattern and time course of neuronal degeneration is compatible with a model where neurons are afflicted by stochastic DNA lesions that can either cause neuronal degeneration by blocking or deregulating expression of essential genes, or trigger genotoxic stress response pathways, for instance, by stalling of RNA polymerase II (de Waard et al., 2010; Garinis et al., 2009; Mitchell et al., 2003; Hoeijmakers, 2009; Nouspikel, 2007; Brooks, 2008). Ercc1 mutants show impaired nucleotide excision repair, interstrand crosslink repair, and double-strand break repair, and hence may accumulate different types of DNA lesions (Houtsmuller et al., 1999; Zhu et al., 2003; Ahmad et al., 2008; Bergstralh and Sekelsky, 2008; Bhagwat et al., 2009). Oxidative base 
damage such 7,8-dihydro-8-oxoguanine (8-oxoG) is repaired by the base excision repair pathway and may not accumulate in Ercc1 mutant mice. However, other oxidative lesions such as malondialdehyde adducts and 8,5' -cyclopurine-2' -deoxynucleotides are both NER substrates and potential threats to transcription (Fishel et al., 2007; Nouspikel, 2007; Brooks, 2008). However, directly determining physiological levels of heterogeneous types of DNA damage in mammalian organs and tissues in a quantitatively reliable manner is extremely challenging and reliable for a very limited subset of lesions (Dizdaroglu et al., 2002; Himmelstein et al., 2009). Hence, the precise lesions that accumulate in Ercc1-deficient neurons remain to be determined.

In addition to the neuropathological changes, we observed an age-dependent impairment in synaptic plasticity in the global Erccl mutant and in synaptic plasticity as well as learning in the neuron-specific Ercc1 mutant. The strong resemblance of phenotypes in the global and the neuron-specific Ercc1 mutants indicate that synaptic plasticity and learning defects in the global Erccl $^{\Delta /-}$ mutant result from the Erccl deficiency in principal forebrain neurons, rather than from indirect effects in other tissues.

How does the lack of a fully functional DNA repair system cause a reduction of LTP and impaired learning? There are several possibilities. For instance, it could be a direct result of the observed neuronal degeneration. However this seems unlikely, because as judged by histology, the overall loss of excitatory neurons appears to be very limited. This is in agreement with the electrophysiology, which showed no significant change in the presynaptic fiber volley (a measure for the number of stimulated fibers) and no change in the size of the fEPSP as a function of stimulation strength (a measure for both the number of activated neurons and the efficacy of synaptic transmission). In addition, since LTP is a relative measure of change of synaptic strength, neurons will only contribute to this measure as long as they are able to show synaptic transmission. Hence, LTP will not be affected by a decreased number of neurons. It is therefore more likely that unrepaired DNA damage interferes with transcription of genes necessary for normal neuronal functioning, which results in decreased neuronal plasticity. In this respect, it is interesting to note that the induction phase of LTP appears to be normal in the Erccl mutants but that the later phase is affected. This impairment coincides with the start of the mRNA and protein synthesis-dependent phase of LTP (called late phase LTP; L-LTP) (Kelleher et al., 2004). Notably, L-LTP has been shown to be affected in aged animals (Bach et al., 1999).

Alternatively, the deficits in plasticity and learning could arise from impaired insulin-like growth factor 1 (IGF1) signaling. Both age-matched $\operatorname{Erccl}^{f /+}$ mice.
3 months

B

6 months
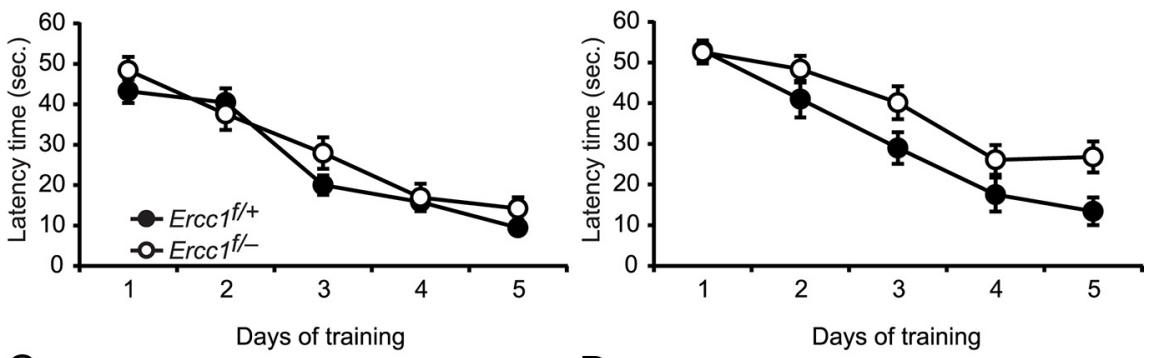

D

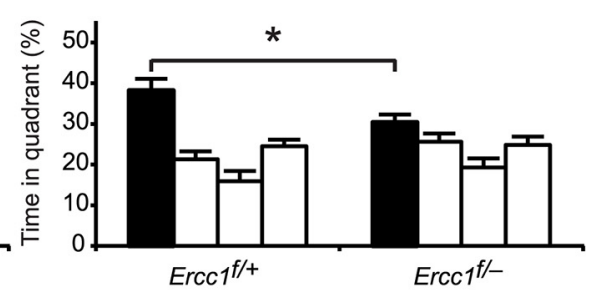

$\mathrm{F}$
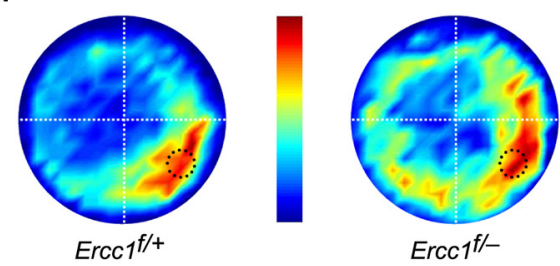

$\mathrm{H}$

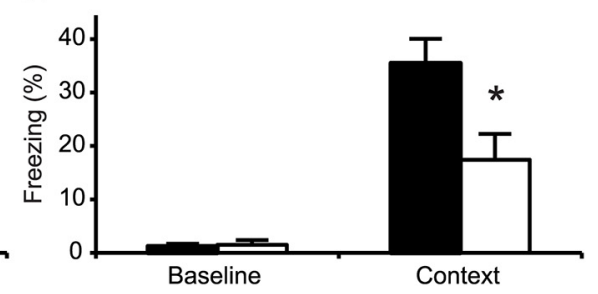

Figure 5. $\quad$ Ercc $^{f /-}$ mice show impaired fear conditioning and impaired water maze performance at 6 months of age. $\boldsymbol{A}, \boldsymbol{B}$, Escape latency of 3-month-old $(\boldsymbol{A})$ and 6-month-old $(\boldsymbol{B})$ mice shows no difference between Ercc $7^{f /-}$ and $\operatorname{Ercc} 7^{f /+}$ mice $(n=9$, $n=15, n=11$, and $n=17$ for 3- and 6-month-old $\operatorname{Ercc}^{f /+}$ and $\operatorname{Ercc}^{f /-}$, respectively). Filled circles represent $\operatorname{Ercc}^{f /+}$. Open circles represent $\mathrm{Ercc}^{\mathrm{f} /-}$. C, D, Quantification of quadrant occupancy in 3-month-old (C) and 6-month-old (D) mice, during the probe trial performed at day 5 . Although all groups searched significantly more in the target quadrant, at 6 months old, Ercc ${ }^{f /-}$ mice spent significantly less time in the target quadrant than their $E r c c 1^{f /+}$ littermates. Black bar represents target quadrant. $\boldsymbol{E}, \boldsymbol{F}$ Visual representation of all search tracks during the probe trial of the 3-month-old $(\boldsymbol{E})$ and 6 -month-old $(\boldsymbol{F})$ mice. The color of the former platform location, respectively. $\mathbf{G}, \boldsymbol{H}$, Contextual fear conditioning in 3-month-old mice $(n=9$ and $n=20$ for $\operatorname{Ercc}^{f /+}$ and $\operatorname{Ercc}^{f /-}$, respectively) $(\boldsymbol{G})$ and 6-month-old mice $\left(n=10\right.$ and $n=13$ for Ercc $^{f /+}$ and Ercc $1^{f /-}$, respectively) placed in the context $24 \mathrm{~h}$ after the shock. All data are reported as mean \pm SEM. *Significantly different $(p<0.05)$ from

DNA damage and aging result in a reduction of the somatotroph axis by downregulating growth hormone $(\mathrm{GH}) / \mathrm{IGF} 1$ signaling (Niedernhofer et al., 2006; van de Ven et al., 2006; van der Pluijm et al., 2007; Garinis et al., 2009), which appears to operate in a cell autonomous way, presumably via DNA damage-induced stalling of RNA polymerase II (Garinis et al., 2009). It has been shown that IGF1 regulates synaptic plasticity in the adult CNS (Torres-Aleman, 1999; Sonntag et al., 2000) and that age-related behavioral impairments can be alleviated by IGF1 (Markowska et al., 1998; Shi et al., 2005), thereby suggesting that IGF1 reduction could be a factor in agerelated reduction of synaptic plasticity. In addition, it has recently been shown that the related family member IGF2 facilitates the sta- 
bility of LTP and is critical for memory consolidation (Chen et al., 2011).

Finally, we cannot exclude that the plasticity deficits are caused by reactive glia, because even though the homozygous Erccl gene deletion was restricted to $\alpha$ CaMKII-expressing neurons, we observed a robust age-dependent increase of GFAP staining, indicative of reactive astrocytosis. GFAP is known to be upregulated in response to neuronal injury and degeneration, and indeed, increased GFAP staining was not observed in wildtype and heterozygous Erccl mutants. To what extend reactive astrocytes can contribute to LTP and learning impairment remains, however, to be investigated (Wenker, 2010).

The observed plasticity deficits and behavioral phenotype of the Ercc1 mouse, parallel findings in aged animals, as impairments in LTP, contextual conditioning, and spatial learning are commonly observed in aged rodents (Bach et al., 1999; Foster et al., 2001; Liu et al., 2002; Watson et al., 2002; Barnes, 2003; Blalock et al., 2003; Blank et al., 2003; Erickson and Barnes, 2003; Foster et al., 2003; Rosenzweig and Barnes, 2003; Verbitsky et al., 2004; Moyer and Brown, 2006; Kaczorowski and Disterhoft, 2009). In addition, some AD mouse models also show reduced LTP and learning (Lambert et al., 1998; Chapman et al., 1999; Walsh et al., 2002; Wang et al., 2002; Jacobsen et al., 2006; Laurén et al., 2009). Also, humans show an age-related deficit in performance on a virtual Morris water maze (Driscoll et al., 2003).

Together, our results show that unrepaired DNA damage is sufficient to cause progressive neuronal pathology, neuronal plasticity deficits, and cognitive decline. The phenotype of the Ercc1 mutants is reminiscent of the global structural and functional deterioration associated with aging. Therefore, we propose that the mouse model(s) mimic(s) aspects of neuroaging. Further experiments are required to more precisely determine which types of toxic DNA lesions accumulate in the Erccl nervous system, to which extent these lesions occur in the aging brain, and by which mechanisms these lesions affect neuronal function. Nevertheless, at this point the mice represent a unique model system to identify conditions that accelerate or prevent the accumulation of toxic DNA lesions. The results of these studies may prove to be important for the development of better therapeutic strategies to battle age-related cognitive decline or to prevent the devastating effects of neurodegenerative diseases.

\section{References}

Ahles TA, Saykin AJ (2007) Candidate mechanisms for chemotherapyinduced cognitive changes. Nat Rev Cancer 7:192-201.

Ahmad A, Robinson AR, Duensing A, van Drunen E, Beverloo HB, Weisberg DB, Hasty P, Hoeijmakers JH, Niedernhofer LJ (2008) ERCC1-XPF endonuclease facilitates DNA double-strand break repair. Mol Cell Biol 28:5082-5092.

Bach ME, Barad M, Son H, Zhuo M, Lu YF, Shih R, Mansuy I, Hawkins RD, Kandel ER (1999) Age-related defects in spatial memory are correlated with defects in the late phase of hippocampal long-term potentiation in vitro and are attenuated by drugs that enhance the cAMP signaling pathway. Proc Natl Acad Sci U S A 96:5280-5285.

Barnes CA (2003) Long-term potentiation and the ageing brain. Philos Trans R Soc Lond B Biol Sci 358:765-772.

Bergstralh DT, Sekelsky J (2008) Interstrand crosslink repair: can XPFERCC1 be let off the hook? Trends Genet 24:70-76.

Bhagwat N, Olsen AL, Wang AT, Hanada K, Stuckert P, Kanaar R, D'Andrea A, Niedernhofer LJ, McHugh PJ (2009) XPF-ERCC1 participates in the Fanconi anemia pathway of cross-link repair. Mol Cell Biol 29:6427-6437.

Blalock EM, Chen KC, Sharrow K, Herman JP, Porter NM, Foster TC, Landfield PW (2003) Gene microarrays in hippocampal aging: statistical profiling identifies novel processes correlated with cognitive impairment. J Neurosci 23:3807-3819.
Blank T, Nijholt I, Kye MJ, Radulovic J, Spiess J (2003) Small-conductance, $\mathrm{Ca} 2+$-activated $\mathrm{K}+$ channel SK3 generates age-related memory and LTP deficits. Nat Neurosci 6:911-912.

Brooks PJ (2008) The 8,5'-cyclopurine-2'-deoxynucleosides: candidate neurodegenerative DNA lesions in xeroderma pigmentosum, and unique probes of transcription and nucleotide excision repair. DNA Repair (Amst) 7:1168-1179.

Cai Q, Tian L, Wei H (1996) Age-dependent increase of indigenous DNA adducts in rat brain is associated with a lipid peroxidation product. Exp Gerontol 31:373-385

Chapman PF, White GL, Jones MW, Cooper-Blacketer D, Marshall VJ, Irizarry M, Younkin L, Good MA, Bliss TV, Hyman BT, Younkin SG, Hsiao KK (1999) Impaired synaptic plasticity and learning in aged amyloid precursor protein transgenic mice. Nat Neurosci 2:271-276.

Chen DY, Stern SA, Garcia-Osta A, Saunier-Rebori B, Pollonini G, BambahMukku D, Blitzer RD, Alberini CM (2011) A critical role for IGF-II in memory consolidation and enhancement. Nature 469:491-497.

Chung YH, Shin C, Kim MJ, Lee B, Park KH, Cha CI (2000) Immunocytochemical study on the distribution of p53 in the hippocampus and cerebellum of the aged rat. Brain Res 885:137-141.

de Waard MC, van der Pluijm I, Zuiderveen Borgesius N, Comley LH, Haasdijk ED, Rijksen Y, Ridwan Y, Zondag G, Hoeijmakers JH, Elgersma Y, Gillingwater TH, Jaarsma D (2010) Age-related motor neuron degeneration in DNA repair-deficient Erccl mice. Acta Neuropathol 120:461-475.

Dizdaroglu M, Jaruga P, Birincioglu M, Rodriguez H (2002) Free radicalinduced damage to DNA: mechanisms and measurement. Free Radic Biol Med 32:1102-1115.

Doig J, Anderson C, Lawrence NJ, Selfridge J, Brownstein DG, Melton DW (2006) Mice with skin-specific DNA repair gene (Ercc1) inactivation are hypersensitive to ultraviolet irradiation-induced skin cancer and show more rapid actinic progression. Oncogene 25:6229-6238.

Dorszewska J, Adamczewska-Goncerzewicz Z (2004) Oxidative damage to DNA, p53 gene expression and p53 protein level in the process of aging in rat brain. Respir Physiol Neurobiol 139:227-236.

Driscoll I, Hamilton DA, Petropoulos H, Yeo RA, Brooks WM, Baumgartner RN, Sutherland RJ (2003) The aging hippocampus: cognitive, biochemical and structural findings. Cereb Cortex 13:1344-1351.

Erickson CA, Barnes CA (2003) The neurobiology of memory changes in normal aging. Exp Gerontol 38:61-69.

Fan F, Jin S, Amundson SA, Tong T, Fan W, Zhao H, Zhu X, Mazzacurati L, Li X, Petrik KL, Fornace AJ Jr, Rajasekaran B, Zhan Q (2002) ATF3 induction following DNA damage is regulated by distinct signaling pathways and over-expression of ATF3 protein suppresses cells growth. Oncogene 21:7488-7496.

Fanselow MS (1990) Factors governing one-trial contextual conditioning. Anim Learn Behav 18:264-270.

Fishel ML, Vasko MR, Kelley MR (2007) DNA repair in neurons: so if they don't divide what's to repair? Mutat Res 614:24-36.

Foster TC, Sharrow KM, Masse JR, Norris CM, Kumar A (2001) Calcineurin links $\mathrm{Ca}^{2+}$ dysregulation with brain aging. J Neurosci 21:4066-4073.

Foster TC, Sharrow KM, Kumar A, Masse J (2003) Interaction of age and chronic estradiol replacement on memory and markers of brain aging. Neurobiol Aging 24:839-852.

Garinis GA, Uittenboogaard LM, Stachelscheid H, Fousteri M, van Ijcken W, Breit TM, van Steeg H, Mullenders LH, van der Horst GT, Brüning JC, Niessen CM, Hoeijmakers JH, Schumacher B (2009) Persistent transcription-blocking DNA lesions trigger somatic growth attenuation associated with longevity. Nat Cell Biol 11:604-615.

Gedik CM, Grant G, Morrice PC, Wood SG, Collins AR (2005) Effects of age and dietary restriction on oxidative DNA damage, antioxidant protection and DNA repair in rats. Eur J Nutr 44:263-272.

Hai T, Wolfgang CD, Marsee DK, Allen AE, Sivaprasad U (1999) ATF3 and stress responses. Gene Expr 7:321-335.

Hamilton ML, Van Remmen H, Drake JA, Yang H, Guo ZM, Kewitt K, Walter CA, Richardson A (2001) Does oxidative damage to DNA increase with age? Proc Natl Acad Sci U S A 98:10469-10474.

Himmelstein MW, Boogaard PJ, Cadet J, Farmer PB, Kim JH, Martin EA, Persaud R, Shuker DE (2009) Creating context for the use of DNA adduct data in cancer risk assessment: II. Overview of methods of identification and quantitation of DNA damage. Crit Rev Toxicol 39:679-694. 
Hoeijmakers JH (2009) DNA damage, aging, and cancer. N Engl J Med 361:1475-1485.

Houtsmuller AB, Rademakers S, Nigg AL, Hoogstraten D, Hoeijmakers JH, Vermeulen W (1999) Action of DNA repair endonuclease ERCC1/XPF in living cells. Science 284:958-961.

Jaarsma D, Postema F, Korf J (1992) Time course and distribution of neuronal degeneration in the dentate gyrus of rat after adrenalectomy: a silver impregnation study. Hippocampus 2:143-150.

Jaarsma D, Haasdijk ED, Grashorn JA, Hawkins R, van Duijn W, Verspaget HW, London J, Holstege JC (2000) Human Cu/Zn superoxide dismutase (SOD1) overexpression in mice causes mitochondrial vacuolization, axonal degeneration, and premature motoneuron death and accelerates motoneuron disease in mice expressing a familial amyotrophic lateral sclerosis mutant SOD1. Neurobiol Dis 7:623-643.

Jacobsen JS, Wu CC, Redwine JM, Comery TA, Arias R, Bowlby M, Martone R, Morrison JH, Pangalos MN, Reinhart PH, Bloom FE (2006) Earlyonset behavioral and synaptic deficits in a mouse model of Alzheimer's disease. Proc Natl Acad Sci U S A 103:5161-5166.

Kaczorowski CC, Disterhoft JF (2009) Memory deficits are associated with impaired ability to modulate neuronal excitability in middle-aged mice. Learn Mem 16:362-366.

Kelleher RJ 3rd, Govindarajan A, Tonegawa S (2004) Translational regulatory mechanisms in persistent forms of synaptic plasticity. Neuron 44:59-73.

Keller JN, Schmitt FA, Scheff SW, Ding Q, Chen Q, Butterfield DA, Markesbery WR (2005) Evidence of increased oxidative damage in subjects with mild cognitive impairment. Neurology 64:1152-1156.

Konat GW, Kraszpulski M, James I, Zhang HT, Abraham J (2008) Cognitive dysfunction induced by chronic administration of common cancer chemotherapeutics in rats. Metab Brain Dis 23:325-333.

Kraemer KH, Patronas NJ, Schiffmann R, Brooks BP, Tamura D, DiGiovanna JJ (2007) Xeroderma pigmentosum, trichothiodystrophy and Cockayne syndrome: a complex genotype-phenotype relationship. Neuroscience 145:1388-1396.

Lambert MP, Barlow AK, Chromy BA, Edwards C, Freed R, Liosatos M, Morgan TE, Rozovsky I, Trommer B, Viola KL, Wals P, Zhang C, Finch CE, Krafft GA, Klein WL (1998) Diffusible, nonfibrillar ligands derived from Abeta1-42 are potent central nervous system neurotoxins. Proc Natl Acad Sci U S A 95:6448-6453.

Laurén J, Gimbel DA, Nygaard HB, Gilbert JW, Strittmatter SM (2009) Cellular prion protein mediates impairment of synaptic plasticity by amyloid-beta oligomers. Nature 457:1128-1132.

Lawrence NJ, Sacco JJ, Brownstein DG, Gillingwater TH, Melton DW (2008) A neurological phenotype in mice with DNA repair gene Ercc1 deficiency. DNA Repair (Amst) 7:281-291.

Lehmann AR (2003) DNA repair-deficient diseases, xeroderma pigmentosum, Cockayne syndrome and trichothiodystrophy. Biochimie 85:1101-1111.

Leutner S, Eckert A, Müller WE (2001) ROS generation, lipid peroxidation and antioxidant enzyme activities in the aging brain. J Neural Transm 108:955-967.

Levine AJ, Hu W, Feng Z (2006) The P53 pathway: what questions remain to be explored? Cell Death Differ 13:1027-1036.

Liu J, Head E, Gharib AM, Yuan W, Ingersoll RT, Hagen TM, Cotman CW, Ames BN (2002) Memory loss in old rats is associated with brain mitochondrial decay and RNA/DNA oxidation: partial reversal by feeding acetyl-L-carnitine and/or R-alpha -lipoic acid. Proc Natl Acad Sci U S A 99:2356-2361.

Logue SE, Martin SJ (2008) Caspase activation cascades in apoptosis. Biochem Soc Trans 36:1-9.

Lovell MA, Markesbery WR (2007) Oxidative DNA damage in mild cognitive impairment and late-stage Alzheimer's disease. Nucleic Acids Res 35:7497-7504.

Madisen L, Zwingman TA, Sunkin SM, Oh SW, Zariwala HA, Gu H, Ng LL, Palmiter RD, Hawrylycz MJ, Jones AR, Lein ES, Zeng H (2010) A robust and high-throughput Cre reporting and characterization system for the whole mouse brain. Nat Neurosci 13:133-140.

Markowska AL, Mooney M, Sonntag WE (1998) Insulin-like growth factor-1 ameliorates age-related behavioral deficits. Neuroscience $87: 559-569$

McWhir J, Selfridge J, Harrison DJ, Squires S, Melton DW (1993) Mice with DNA repair gene (ERCC-1) deficiency have elevated levels of p53, liver nuclear abnormalities and die before weaning. Nat Genet 5:217-224.

Mitchell JR, Hoeijmakers JH, Niedernhofer LJ (2003) Divide and conquer: nucleotide excision repair battles cancer and ageing. Curr Opin Cell Biol $15: 232-240$

Møller P, Løhr M, Folkmann JK, Mikkelsen L, Loft S (2010) Aging and oxidatively damaged nuclear DNA in animal organs. Free Radic Biol Med 48:1275-1285.

Moyer JR Jr, Brown TH (2006) Impaired trace and contextual fear conditioning in aged rats. Behav Neurosci 120:612-624.

Muñoz P, Blanco R, Flores JM, Blasco MA (2005) XPF nuclease-dependent telomere loss and increased DNA damage in mice overexpressing TRF2 result in premature aging and cancer. Nat Genet 37:1063-1071.

Nance MA, Berry SA (1992) Cockayne syndrome: review of 140 cases. Am J Med Genet 42:68-84.

Nichols NR, Day JR, Laping NJ, Johnson SA, Finch CE (1993) GFAP mRNA increases with age in rat and human brain. Neurobiol Aging 14:421-429.

Niedernhofer LJ, Garinis GA, Raams A, Lalai AS, Robinson AR, Appeldoorn E, Odijk H, Oostendorp R, Ahmad A, van Leeuwen W, Theil AF, Vermeulen W, van der Horst GT, Meinecke P, Kleijer WJ, Vijg J, Jaspers NG, Hoeijmakers JH (2006) A new progeroid syndrome reveals that genotoxic stress suppresses the somatotroph axis. Nature 444:1038-1043.

Nouspikel T (2007) DNA repair in differentiated cells: some new answers to old questions. Neuroscience 145:1213-1221.

O'Callaghan JP, Miller DB (1991) The concentration of glial fibrillary acidic protein increases with age in the mouse and rat brain. Neurobiol Aging 12:171-174

Paxinos G, Franklin KBJ (2001) The mouse brain in stereotaxic coordinates, Ed 2. San Diego: Academic.

Rosenzweig ES, Barnes CA (2003) Impact of aging on hippocampal function: plasticity, network dynamics, and cognition. Prog Neurobiol 69:143-179.

Selfridge J, Hsia KT, Redhead NJ, Melton DW (2001) Correction of liver dysfunction in DNA repair-deficient mice with an ERCC1 transgene. Nucleic Acids Res 29:4541-4550.

Serrano F, Klann E (2004) Reactive oxygen species and synaptic plasticity in the aging hippocampus. Ageing Res Rev 3:431-443.

Shi L, Linville MC, Tucker EW, Sonntag WE, Brunso-Bechtold JK (2005) Differential effects of aging and insulin-like growth factor-1 on synapses in CA1 of rat hippocampus. Cereb Cortex 15:571-577.

Sijbers AM, van der Spek PJ, Odijk H, van den Berg J, van Duin M, Westerveld A, Jaspers NG, Bootsma D, Hoeijmakers JH (1996) Mutational analysis of the human nucleotide excision repair gene ERCC1. Nucleic Acids Res 24:3370-3380.

Sohal RS, Agarwal S, Candas M, Forster MJ, Lal H (1994) Effect of age and caloric restriction on DNA oxidative damage in different tissues of C57BL/6 mice. Mech Ageing Dev 76:215-224.

Sonntag WE, Bennett SA, Khan AS, Thornton PL, Xu X, Ingram RL, BrunsoBechtold JK (2000) Age and insulin-like growth factor-1 modulate $\mathrm{N}$-methyl-D-aspartate receptor subtype expression in rats. Brain Res Bull 51:331-338.

Takahashi T, Amano N, Asamura H, Nomiyama T, Hanihara T, Nakayama J, Fukushima H (2006) Correlation between glial fibrillary acidic proteinpositive astrocytes and age in the human hippocampus. Leg Med (Tokyo) 8:161-165.

Torres-Aleman I (1999) Insulin-like growth factors as mediators of functional plasticity in the adult brain. Horm Metab Res 31:114-119.

Tsien JZ, Huerta PT, Tonegawa S (1996a) The essential role of hippocampal CA1 NMDA receptor-dependent synaptic plasticity in spatial memory. Cell 87:1327-1338.

Tsien JZ, Chen DF, Gerber D, Tom C, Mercer EH, Anderson DJ, Mayford M, Kandel ER, Tonegawa S (1996b) Subregion- and cell type-restricted gene knockout in mouse brain. Cell 87:1317-1326.

Turchi L, Fareh M, Aberdam E, Kitajima S, Simpson F, Wicking C, Aberdam D, Virolle T (2009) ATF3 and p15PAF are novel gatekeepers of genomic integrity upon UV stress. Cell Death Differ 16:728-737.

van der Pluijm I, Garinis GA, Brandt RM, Gorgels TG, Wijnhoven SW, Diderich KE, de Wit J, Mitchell JR, van Oostrom C, Beems R, Niedernhofer LJ, Velasco S, Friedberg EC, Tanaka K, van Steeg H, Hoeijmakers JH, van der Horst GT (2007) Impaired genome maintenance suppresses the growth hormone-insulin-like growth factor 1 axis in mice with Cockayne syndrome. PLoS Biol 5:e2.

van de Ven M, Andressoo JO, Holcomb VB, von Lindern M, Jong WM, De Zeeuw CI, Suh Y, Hasty P, Hoeijmakers JH, van der Horst GT, Mitchell JR 
(2006) Adaptive stress response in segmental progeria resembles longlived dwarfism and calorie restriction in mice. PLoS Genet 2:e192.

Verbitsky M, Yonan AL, Malleret G, Kandel ER, Gilliam TC, Pavlidis P (2004) Altered hippocampal transcript profile accompanies an agerelated spatial memory deficit in mice. Learn Mem 11:253-260.

Vlug AS, Teuling E, Haasdijk ED, French P, Hoogenraad CC, Jaarsma D (2005) ATF3 expression precedes death of spinal motoneurons in amyotrophic lateral sclerosis-SOD1 transgenic mice and correlates with c-Jun phosphorylation, CHOP expression, somato-dendritic ubiquitination and Golgi fragmentation. Eur J Neurosci 22:1881-1894.

Walsh DM, Klyubin I, Fadeeva JV, Cullen WK, Anwyl R, Wolfe MS, Rowan MJ, Selkoe DJ (2002) Naturally secreted oligomers of amyloid beta protein potently inhibit hippocampal long-term potentiation in vivo. Nature 416:535-539.

Wang HW, Pasternak JF, Kuo H, Ristic H, Lambert MP, Chromy B, Viola KL, Klein WL, Stine WB, Krafft GA, Trommer BL (2002) Soluble oligomers of beta amyloid (1-42) inhibit long-term potentiation but not long-term depression in rat dentate gyrus. Brain Res 924:133-140.
Wang J, Xiong S, Xie C, Markesbery WR, Lovell MA (2005) Increased oxidative damage in nuclear and mitochondrial DNA in Alzheimer's disease. J Neurochem 93:953-962.

Watson JB, Khorasani H, Persson A, Huang KP, Huang FL, O’Dell T] (2002) Age-related deficits in long-term potentiation are insensitive to hydrogen peroxide: coincidence with enhanced autophosphorylation of Ca2 + /calmodulin-dependent protein kinase II. J Neurosci Res 70:298-308.

Weeda G, Donker I, de Wit J, Morreau H, Janssens R, Vissers CJ, Nigg A, van Steeg H, Bootsma D, Hoeijmakers JH (1997) Disruption of mouse ERCC1 results in a novel repair syndrome with growth failure, nuclear abnormalities and senescence. Curr Biol 7:427-439.

Wenker I (2010) An active role for astrocytes in synaptic plasticity? J Neurophysiol 104:1216-1218.

Zhu XD, Niedernhofer L, Kuster B, Mann M, Hoeijmakers JH, de Lange T (2003) ERCC1/XPF removes the 3' overhang from uncapped telomeres and represses formation of telomeric DNA-containing double minute chromosomes. Mol Cell 12:1489-1498. 